\title{
Læserens næse
}

om den tekstlige topografi i Lawrence Norfolks romaner

TORe Rye ANDERSEN

Litteraturens rum

belastede âr 1984 identificerede Fredric Jameson i sit banebrydende essay „Postmodernism, or, the Cultural Logic of Late Capitalism et af de centrale aspekter ved det postmoderne: ,vores daglige liv, vores psykiske erfaring, vore kulturelle sprog, bliver i dag domineret af rumlige snarere end tidslige kategorier" '(s.64, min overset telse). Den spatile vending har manifesteret sig intelse). Den sp ille vig inden for nasten alle by litteraturen. Huor modenis ons vige varke ofte var grundige undersogelser af tiden som eksistensvilkàr (Pá sporet af den tabte tia, Clysses, Mrs Dalloway), har postmodernismen været karakterisere ved et epistemologisk skift $i$ retning af det topografiske. I en læsning af Peer Hultbergs Byen og verden har Jan Kjærstad sat sagen pà spidsen. , I dagens litteratur står Stedet i frontlinien, ikke Tiden" (s. 2I).

Den spatiale dominans i nyere litteratur ytrer sis på flere forskellige måder. En af 'dem er, at Stedet langt oftere end tidligere optræder som en decidere hovedperson i de litterære tekster ${ }^{I}$ Et andet - Og mener jog vistigere - udag er, at telstet - og selv bliver koncipet som rum at telstene ofte

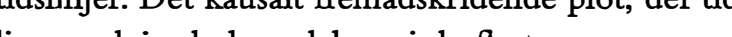
ligere udgjorde hovedaksen i de teste romaner, er et litterært opgør med Newtonsk determinisme blevet hugget op, vredet, vendt og opløst som holdepunkt for læseren, der i stedet er blevet kastet ud en forvirrende tekstlig topografi. En diskussion om de nye spatiale tekstbegreber ender imidlertid selv med at blive desorienterende, hvis ikke man etablerer nogle faste referencepunkter, så i det følgende vil

PASSAGE $3 T / 32-$ IOg9 jeg forankre min undersøgelse i en af de forfattere, som tydeligst praktiserer en spatial litteratur.

Den engelske forfatter Lawrence Norfolk (f. r963) står som en af de fremmeste repræsentante for Jamesons teori om det rumliges dominans, men samtidig modarbejder han Jamesons ide om, at vi lever $i$ et historieløst samfund. Norfolk har nemlig slerevet to lange kalejdoskopiske historiske romaner skevet to lange kalejdoskopiske's historiske romane Lempritres Dictionary og The Pope's Rhinoceros, der detaljerigdom og samvitughedsfuld researcharbejd ikke står tilbage rieskrivning.

Norfolk debuterede som blot 28-årig med Lemprière's Dictionary (1991), der høstede mange anmelderroser. Han havde aldrig for udgivet så meget som en enkelt novelle, og debutromanen fremstår i dette lys særligt imponerende pga. dens uhyre kompleksitet og forfatterens sikre kontrol over sit materiale. foråret $1996 \mathrm{kom}$ så efterfølgeren, murstenen The Pope's Rhinoceros, der i længde såvel som kompleksitet overgår Lemprière's Dictionary. Norfolk er blevet sammenlignet med forfattere som Dickens, Joyce, Thomas Pynct Thom le er i vinkeligheden for onignale ti, at sådanne Det er d belle ilke het for alvor er beretigede. Det er da heller ikke helt problemfrit at indplacere ham $i$ en litterær kontekst. I den engelske roman har der aldrig været tradition for den blanding af informationsmættet kompleksitet og pop-kultur, som Norfolk udøver, og $\mathrm{i}$ den henseende ligger han måske tættere på den amerikanske tradition, der strækker sig fra William Gaddis, over Thomas Pynchon og John Barth og til David Foster Wallace. Som et resultat af deres tone, deres scene og deres histo- 
riske stof lnytter Norfolks romaner sig dog utvivlsomt til den Gamle Verden, til Europa. Fusionen af amerikansk æstetik og europæiske, historiske emner placerer altså Lemprière's Dictionary og The Pope's Rhinoceros et eller andet sted ude over Athorerovet, Rhinocers et eller ancet sted ude over Atlanterhavet, omleing den 35. langdegrad, i en unik men også noget ensom position på det litteraturhistoriske ver-
denskort.

Helt alene er Norfolks to romaner imidlertid ikke de har jo hinanden. Parallellerne mellem bøgerne er nemlig talrige. De er begge historiske romaner med hele Europa som deres scene (og deres emne). Begge foregår umiddelbart før store historiske omvæltninger (hhv. den Franske Revolution og Reformationen). De to lange, komplekse romaner er begge ekstremt velresearchede og inkorporerer enorme mængder historisk og encyklopædisk viden. God is in the detail"،, har Norfolk sogt, ${ }^{2}$ og hans "God is in the detals" of romaner er $i$ forlængel mereren ind $i$ en fotidg verden af eksotiske sanseindtryk og informationer. Nar hovedpersonen John Lemprière fra debutromanen overraskes af et pludseligt regnskyl, så er det fordi det rent faktisk regnede hin efterårsdag i London anno 7788 , og når John i forbifarten hører, at guldprisen på en bestemt dag er $3 \mathrm{II}$. I7s. Io.sd. pr. oz., så kan man roligt stole på, at det passer.

Et sidste afgørende fællestræk for Norfolks roman-duo er det topografiske, som spiller en hovedrolle fra start til slut. Romanerne er spækkede med skildringer af topografier, og Norfolks landskabs- og bybeskrivelser er blandt de bedste i moderne prosa. byber (Lon (Lond Rly Pans), Letiper den in Popes Rhyocess), biver den in en kalejdoskopisk panorering; en tret beskrivelse, der strækker sig over mange sider og virkelig giver læseren følelsen af at være ankommet til en fremmed by fyldt med ukendte og forvirrende sanseindtryk.

I tråd med den tendens jeg skitserede tidligere, er romanerne også selv $i$ en vis forstand at opfatte som tekstlige landskaber, men i Norfolks gestaltning af teksternes egen topografi ligger til gengæld en væsentlig forskel på de to romaner, som jeg skal undersøge i det følgende. Denne forskel har store konsekvenser, ikke mindst for læserens rolle i fortolkgeografi.

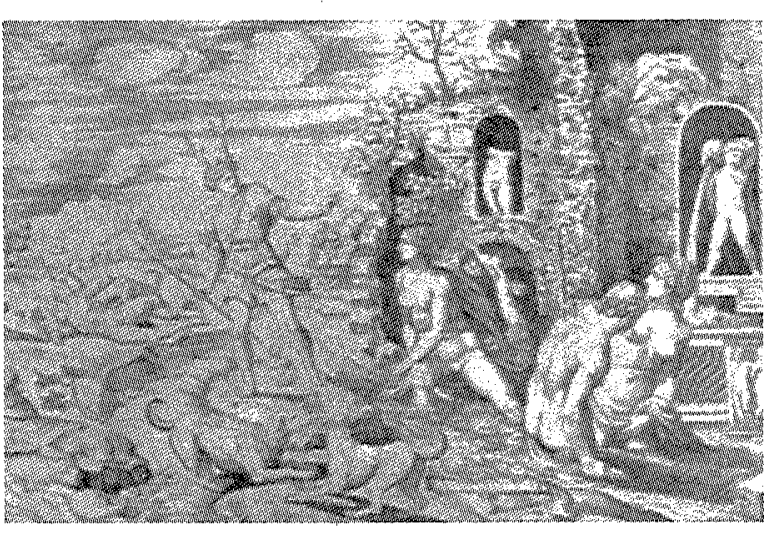

Diana og Akteon. Marc Antoine Raimondis atelier.

Alting ser klarere ud oppefra. (Clint Eastwood i En nevefuld dollars)

Med nasen i skyeme

Lemprière's Dictionary er på alle måder en stor debutroman. ${ }^{3}$ Norfolks første bog er en bredt orkestreret fortælling om den historiske person John Lemprière, der i slutningen af $1700-$ tallet skrev den oprindelige Lemprière's Dictionary, et opslagsværk om gresk mytologi. I løbet af sin godt 600 sider lange roman knyitter Nörfolk udgivelsen af det klassiske opslagsværk sammen med grundlæggelsen af verden måske første multinationale selskab - East India Company - i år 1600 med Richelieus - East India Compering af $l_{a}$ Cocholution, 200 år. Da Lemprières far omkommer ved en 'jagtulykke' på Jersey, forlader Lemprière fødeøen og drager til London, hvor han under arbejdet med at bringe orden i sin fars efterladte papirer kommer på sporet af en omfattende sammensværgelse. En hemmelig organisation, Kabbalaen, har fra hjertet af East India Company trukket $i$ trådene på den europæiske stor-
Politiske scene igennem mere end 100 år, og har for tiden gang $i$ et stort projekt, der skal implementeres i Frankrig den I4. juli 1789. Den gedulgte Kabbala holder til i Londons undergrund, $i$ de fossilerede rester of et kolossalt Dyr, hvis storrelse mo have foet rester af et lolose ma have faet Godzilla til at frema John ster sonkespil og sætter sig for at komme til bunds i sagen. Undervejs i opklaringsarbejdet kommer han ud for mange hændelser, der på sælsom vis genspejler de personer og begivenheder fra den græske mytologi, han er i færd med at nedfælde i sit opslagsværk. Han fortsætter dog ufortrødent og med hjælp - og modstand - fra et enormt persongalleri, som omfatter indiske lejemordere, benløse søkaptajner, robotter, 80-årige pirater og en enkelt engel, lykkes det Lemprière at opdage Kabbalaens hemmelighed, dens relation til belejringen af la Rochelle og sin egen uvildige involvering $i$ den store sammensværgelse....og så fâr han oven $i$ købet også den smukke pige til slut (om end ikke det halve kongerige).

Så langt så godt. Umiddelbart kunne Lemprière's Dictionary lyde som en traditionel eventyrroman a la f.eks. Dumas' underholdende fortællinger. Men der er dog andet og mere på færde i det uendeligt komplicerede plot, som ovenstående handlingsreferat langt fra kan yde retfærdighed. Vejen til romanens bogstaveligt talt eksplosive klimaks er nemlig så snirklet, at den næppe kan kaldes en vej, hvis man ved 'vej' forstår en konstruktion, der skal kunne fungere som en forholdsvist rationel rute mellem to punkter. Dybdeperspektivet i romanens paranoide univers (der har en oplagt parallel i TV-serien $X-f i$ les) er mildest talt svimlende. Der tales bele tiden les) er middest tilten om skjule med stor maje har afleck et af dem, ja så aner man straks nye skjulte mønstre bag tekstens nye overflade. Forbindelserne prolifererer og plottet bifurkerer i kaotiske knopskydninger, der konstant truer med at overvælde Lempriére såvel som den forvirrede læser.

Denne uoverskuelighed udspringer ikke af forfatterens manglende kontrol med materialet, men er resultatet af en bevidst strategi. I et interview i Griflen har Norfolk således sag:
Forskellen på historien som den blev levet, i modsetning til historien som den er skrevet ned, er et spørgsmål om ikke at kende slutningen. En af mine pointer er, at ingen af persoved at de lever umiddelbert for den fronse revolution, i en fnntastisk vigtig tid Denne tivil har jeg allegorisk forsøgt at overfore på mine lesere, da jeg jo ikke kan fratage dem deres historiske viden.

Med et kompliceret og detaljeret plot bliver det umuligt at have overblik, man skal hele tiden vare en anelse bekymret over, hvor meget af historien eller plottet man har hold på. Deter ders tanker og handlinger. For ud over begivenheder er histo作

(Palm, s. I7)

Tvivl er altså en vigtig kategori $\mathrm{i}$ romanen. Ud over at overvælde ham med et detaljerigt plot, fremkalder Norfolk også leserens tvivl ved at gore vold pà (a) en

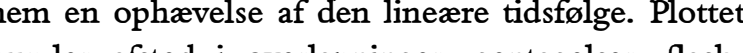
列 backs og flashforwards og inkluderer desuden personer, der har levet giske forbindelser mellem romanens enkelte episoder kan derfor være yderst vanskelige at fả øje på, og i første omgang må man i stedet prove at arbejde med en slags samtidighedsprincip; romanen mange episoder er i denne optik mere at ligne med ærter i en skål end perler på en snor.

En anden væsentlig kronologisk strategi er den bevidste brug af anakronismer. Lemprière's Dictionary foregår i $\mathrm{I} 788$, men ikke desto mindre rummer den sangstumper fra Talking Heads, og et enkelt klavertylke ( Yil ( forfolks side). Endvidere tænker mange af romanpersonerne i en terminologi, der minder betænkeligt om vor dages kaosteori, og endelig har en slet forklædt Thomas Pynchon en ganske kort gæsteoptræden under navnet $\mathrm{O}$ 'Tristero.4 $\mathrm{De}$ mange bevidste anakronismer udgør en indbygget subversion af romanens tidsskema og trækker dens uomgængelige historicitet frem i lyset. Selv om bogen er nøje gennemresearchet og rummer et væld af historisk kor- 
rekte detaljer, så kan den ikke transcendere den tid, den er skrevet i, hvilket Norfolk eksplicit anerkender med sine anakronismer. Udviskningen af de klare distinktioner mellem vor tid og I700-tallet arbejder også den anden vej. Ved at skrive om nogle faktiske historiske tildragelser, der har bla nogle aaktiske historise stykker i vores halvdel af det 20. århundrede, lader Norfolk voo-talle kste lys pa veres egen tid. De hyperaktuelle diskussion om MAI-aftalen og multinationale selskabers magtbeføjelser, samt om retssagen mod Microsoft, har sin tydelige forløber i Eas India Company, der i det 18 . århundrede var en skræmmende international magtfaktor.

Gennem anakronismerne og de mange parallelle mellem Lemprières og vores århundrede kollapses distinktionen mellem nutiden og fortiden. Alt falder ind i det samme rum, romanens rum, der opererer med sin helt egen tidslige logik (eller mangel pa samme). Det er dette rum, Lemprière skal grre sine opdagelser $i$, og det er det samme rum lesere slynges ind $i$ labet af rejen lynges ind 1 lobet af rensen. At Lemprière's Dictionary skal opfattes som et rum understottes af Norfolks mange og lange beskrivelser af det topografiske. Der lægges ikke blot vægt pa hvad der sker, men også på hvor det sker. Romanpersonernes omgivelser gores til genstand for tætte, desorienterende beskrivelser, hvoraf et af de bedste eksempler er Johns første møde med London (LD, 66-7I). Efter en udmattende rejse fra Jersey ankommer han til storbyen gennem Fleet Market på en travl arbejdsdag. Mødet med det pulserende marked overvælder den stakkels John, der fra alle sider bombarderes med overvældende sanseindtryk, $i$ en beskrivelse der lober over flere tætskrevne sider. Lx seren har ikke nogen mériden $i$ forhold til Jobseren har ilke nog mohn met ret af ming af romanen vil det vise sig, at nogle af de personer og informationer, der vrimler omkring John, senere vil spille en vigtig rolle i plottet, men det aner han ikke, og det ved læseren heller ikke første gang. Lemprières første møde med London har en oplagt parallel $\mathrm{i}$ læserens første møde med romanen og fungerer som en mise-en-abyme på læsningens vilkår (uden dog at kunne reduceres entydigt til dette)
Romanen er i det hele taget rig på forvirrende topografiske beskrivelser - det fossile Bæst i Londons undergrund, East India Companys vældige arkive, et landsted lidt uden for byen, Paris osv. - der direkte modarbejder ethvert forsog på at danne sig overblik. Disse tætskrevne passager er alle (minds) doviter (minds) dobbla boskrivelser af leder pa johns opldarigsarbejte, som afspejlinger af læserens arbejde med at forstå handlingen, og indimellem også som kommentarer til Norfolks egne problemer med at bemestre skriveprocessen. De mange topografiske, uoverskuelige beskrivelser giver læseren fornemmelsen af at være in medias res, som aktiv deltager $i$ en fortløbende proces; at leve midt $\mathrm{i}$ historien snarere end at betragte den keligt og retrospektivt.

Indtil videre kunne man måske have fảet det indtryk, at læsningen af Lemprière's Dictionary er ensbetydende med en permanent tilstand af ridvildhed tydende med en perementer Hvordan kan man overhovedet skabe mening i dette telstige vildnis, hhore vild og blive æodt af heksen i pandekagehuset, inden man selv har nået at æde nogle af hendes pandekager? Der ér imidlertid hjælp at hente $\mathrm{i}$ romanen, både for Lemprière og for læeseren. Allerede $i$ begyndelsen af romanen, inden historien for alvor er begyndt, bliver John mere klarsynet. Han har ellers siden barndommen bevæget sig rundt $\mathrm{i}$ en konstant tåge: „Genstandene blev tågede og smeltede sammen med añdre genstande. Omridsene brast og sivede ind i deres omgivelser" (LD, I8). En så sløret opfattelsesevne er vel ikke lige frem den bedste udganosposition for en vordende mysterieloser, men situaposion for en vordende mystenieloser, men situa( John far nemlig et par briller. Efter at have gået undti en verden af evig nærsynethed, tegner der sig pludselig svimlende perspektiver for ham, og brillerne gør ham $i$ stand til at møde verden med åbne ojne, at indlede opklaringsarbejdet (der skal gøre ham klarsynet på andre måder).

Heller ikke leseren bliver ladt alene $i$ en dis af uklare perceptioner. Norfolk kan ganske vist ikke udstyre hver eneste læser med et par briller, men han kan tilbyde modbilleder til forvirringen på anden vis. Disse modbilleder kommer forst og fremmest $i$ stand gennem en perspektivisk vekselvirkning, der lober gennem hele romanen. Som et alternativ til de mange horisontale perspektiver, der er nert knyttet til forvirring manolende overblik desort ner desorientening, og soms anves i Lemprières ankomst il Long on nem gâdens elementer, opererer Norfolk med vertikale perspektiver - fugleperspektiver - der gor alting klarere. Fugleperspektiverne optræder med jærne mellemrum gennem hele romanen. De først er anonyme og virker ikke knyttet til en bestem person, men efterhånden bliver det klart, at de forbundet med myten om Englen fra la Rochelle. $\mathrm{Da}$ la Rochelle i sin tid brændte og tusinder døde flammerne, beskrev ojenvidner, hvordan et enkelt brændende barn som en anden engel floj væk fra den grusomme massakre. I lobet af romanen antydes det, at fugleperspektiverne udspringer fra denne des det, at fulpers engel, der hilelost lyy manens sidste scene, afslons det at englen identisk med den unge mand Septinus, der gennem hele bogen har fungeret som Johns mere eller mindre trofaste hjælper pa landjorden, samt at han ove i købet er i familie med John.

De vertikale perspektiver, hvor Septimus bogstaveligt talt flyver over begivenhederne, skaber ikk alene klarhed over de plotforbundne elementer, men også over hele det europæiske kontinent, idet han fra sin olympiske position kan se storpolitiske udviklingsmønstre, som er usynlige for personerne det horisontale plan. Overflyvningerne danner et overblik over den Historie, som romanens avrige personer blindt må snuble sig fremad i (i visse til pero bor falde bogind blinde politimand John Fielding, en historisk perso som var bror til forfatteren af Tom Jones, Henry
Fielding).

„Alting ser klarere ud oppefra“, som Clint Eastwood udmærket vidste. Engleperspektiverne afdækker gradvist intrigens mange aspekter, og Lemprière's Dictionary slutter med, at englen Septimus flyve hjem til sine egne, i en udzoomning hvor alle de sid- ste brikker i det indviklede plot falder på plads med et hørbart kjik.

Selv om overflyvningerne foregår som en integreret del af selve plottet, har de også en metafunktion, da de for en stund tillader leseren at lofte en flig af teatertæppet og se maskineriet bag romane Med apter Med ande ord, sa bliver de struncinper, der fomer bogens horisonale plan, synlige fra oven gennem brugen af mise-en-abyme-strukturer. Fra sin priviligerede position kan Septimus se nogle hændelser, som samtidig er slet skjulte beskrivelser af en romanstruktur. En af de væsentligste mise-enabyme-strukturer er beskrivelsen af Kejser Josef og hans våde drømme. Hver nat har Kejseren i søvne lange og mange sædudtømninger og hans sædspor er en veltalende kommentar til romanens form:

Så ville han vågne og se udtomningen af sine behov på lagenet under sic. Indimellem ville han fore en finger lanos de tykke våde stråler, log a merke til konvergenser og sammenfilende følge et andet, eller krydse det og danne en mere håndgribelig klat, og nogle gange spekulerede han på om der, hvis alle disse tilfaldige udladninger blev ekstrapoleret og fulgt fremad i det uendelige, kunne være et punkt, et centralt knudepunkt, hvor de ville konvergere? Kunne der være et punkt hvorfra meningen med det hele ville være helt tydelig?

(ID, 499, min oversettelse)

Og kort efter reflekterer Kejseren: „Hvor førte de hen, disse glinsende spor? [...] Hvad betød den kryptiske slim?““ (LD, 500, m.o.). Lemprière's Dictionary er altså konciperet som en mængde narrative ninger. Indimellem modes vektoreme i betydnings-

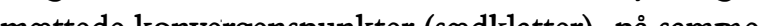
måde som ror og genererer betydning. Romanen kan med andre ord foreløbigt opfattes som et mulighedsfelt, hvilket understottes $i$ endnu en vigtig mise-en-abyme. Kejser Josef må atter stå for skud. Denne gang bevæger han sig forvildet rundt $i$ en lund af appelsintræer og på en omgivende græsplæne. En kraftig brise blæser ind over plænen og den stakkels kejser, der prøver at skabe sig et overblik: 
[...] han blev forvirret, da han lod til at følge en sti, som forte ham i rette vinkler og så i en snæver bue oog snæevrede ind, sa han nu udmerket kunne vere tilbage ved sit udgangspunk igen. Det var ikke til at sige. [...] Han standsede op. Heliografplenen blinkede, tandte og slukkede, pludrede los po sit bnere stakketo, soen dannede smo hulninger los pa sit bjlene $l o g$ il og dene slog tlog fa, hungere og hirtigere, indril meddelelsen blev til ting og her he eneste udgang og indgang svingede bade op og $i$. Forkkellen $p$ dens et- og nul-status snevredes ind til Staten, og i selve Staten krydsede sporene hinanden og spredte sig, påvirkede hinanden og blandedes, handlede og modvirkede hverandre, således at virkefeltet blev et felt af muligheder og nettet af spor en sky, hvor enhver begivenhed, der sandsynligvis ville indtreffe, nesten lige så sikkert ikke indtraf, og nu forekommer, i det mindste set $\mathrm{i}$ dette perspektiv, hele det ergodiske panoptiske ruskomsnusk til overflod blendende klart.

(LD, 502)

Igen trækkes forskellen mellem de to perspektiver tydeligt op. Kejseren er forvirret nede $i$ appelsinluntyden lep. Kejsel den, men set fra et panoptisk perspektiv afsløre dens - og romanens - mønster sig som et mulig hedsfelt af stadigt krydsende vektorer. Forskelle mellem det horisontale og det vertikale er også forskellen mellem landskabet og landkortet, mellem e øjensynligt kaos og en fastlåst orden. Lemprière's Dic tionary er et forsøg på at integrere disse to størrelser, at fusionere "Tilffeldighed og hensigt“ (LD, 367), at opnå en tilstand af „sludder og fornuftig tale forvirret mellem hinanden" (LD, 382). Det er i dette lys bogens mange kaosteoretiske henvisninger skal læses: på trods af sit navn handler kaosteori nemlig lige så meget om orden som kaos, nærmere betegnet om at finde cenkommende strukturer $i$ et jensy at inde genkens par. på rette vej i romanens horisontale plan: jagten $\mathrm{p}$ strukturer, der gentager sig pà forskellige skalae Den vigtigste af disse strukturer er utvivlsomt den brudte cirkel, der er Kabalens vartegn. Gang p gang støder John på brudte cirkler - på farens signetring, $i$ et bibliotek på Jersey, ridset ind $i$ et bord på et værtshus, i selve Kabalens sammensætning og $i$ havnen la Rochelle - og efterhånden lærer han a genkende den og anvende den som pejlepunkt i sin bevægelse gennem plottets topografi. ,Mønstere gentog sig" (LD, 394), og derfor kan Lemprière ti en vis grad skabe mening på det horisontale plan. Endelig klarhed kan dog kun opnås via det vertikale plan.

Forsøget på at integrere de to perspektiver, kaos og orden, $i$ et tredimensionelt mulighedsfelt lykkes imidlertid ikke til perfektion. I sidste ende ér de snarere tale om en vekselvirlming, hvor de to perspektiver forbliver klart adskilte, og hvor fugleperspektivet efter endt læsning ender med at få overtaget. Norfolk prover at få læeseren til at geråde $i$ forvirring, at få ham til at deltage i Historien som den blev levet, men pga. fugleperspektiverne er det endelige indtryk klarhed, og en følelse af skrevet Historie. I løbet af romanen har Lemprière - og til dels også læseren - „snublet og tumlet rundt nedenunder" (LD, 6I7, m.o.), bevæget sig rundt i ,det forvirrede og menneskelige drama nedenunder" (LD, 563, m.o.). Det horisontale nivean, forviringen, sidestilles altså eksplicit med menneskeligingeneligded. Selv om lager $\mathrm{i}$ (ofte sig op over det menneskelige drama, at etablere et panoptisk perspektiv gennem Septimus' „mest-seende øjne" (LD, 564, m.o.), med næsen i skyerne. I sin berømte fængselsbog har Michel Foucault sidestillet det panoptiske perspektiv med Systemets kontrol over individet.7 Fra deres centrale observationstårn kan vogterne styre de indsatte og følge deres mindste bevægelser $i$ en art gudeagtig position. I lōbett af Lemprière's Dictionary bevæger John og læseren sig gradvist fra offerets rolle og hen mod den overvågendes rolle, mod den totale kontrol. Bevæcelsen ekspliciteres og fuldbyrdes på romenens nestsidste side, blevet de m.o.). Dette modsætningspar (på engelsk: preterite/elect) har Norfolk hentet fra Pynchons Gravity's Rainbow, hvor 'de forbigaede' er genstand for sympati, mens 'de udvalgte' sidestilles med Systemets umenneskelige kontrol, og săledes indtager en klar skurkerolle. Efter gennem det meste af romanen at have været ' forbigået', menneskelig og tvivlende, ender læseren altså til sidst i den panoptiske kontrolposition, som
Kabbalaen ellers har indtaget - en position hvorfia alt kan overvåges og styres. Et sådant positionsskif gør nødvendigvis Lemprière's Dictionary lidt etis uklar - hvem skal man egentlig sympatisere med i sidste ende? Jeg tror ikke, denne uklarhed har være tilsigtet fra Norfolks side, men en gang imellem kan der snige sig spøgelser ind i selv de mest velfungerende maskiner.

Ved hjælp af skibet Vineeta, der optræder i slutningen af Norfolks debutroman, kan vi nu bevæge os over til The Pope's Rhinoceros, der er dedikeret til Vineeta, og starter i den sunkne by Vineta. ${ }^{8}$ I denn roman skal læserens indplacering i romanens rum, og i forlængelse heraf hans etiske position, vise sig at være noget mere afklaret og konsistent.

Laser, giv agt! Uforsigtigt har jeg fort dig til toppen af så hoj en bakke som ho Allworthys, og jeg véd ikke ret huord jeg shal bringe dig ned fra sammora jeg skal bringe dig ned fra samme, ude at du brakker halsen. Vi vil dog vove (Henry Fielding: Tom Jones, I, 4)

Med nesen i mulden

The Pope's Rhinoceros er en værdig efterfølger ti Norfolks debutroman. Forfattere lider ellers ofte a et anden-bogs-syndrom, især hvis deres forste bog har været så stor en succes som Lemprière's Dictionary. Norfolk har imidlertid ufortrødent taget udfordringen op og skrevet en godt 700 sider lang roman, der hører til blandt goernes vigtigste europæiske bøger.

Denne gang er scenen Europa i starten af rso0tallet. Renmsancen er goet ind $i$ sine sidste voldsommen lure lige om hor to Romer, tidligere lejesoldater Salvestro og Bernardo, er flygtet fra krigene syd for Alperne tilbage til Salvestro fødeø Usedom. Under et latterligt forsøg på at finc den sunkne by Vineta $i$ en utæt tønde møder de en afsondret munkeorden, der efterfølgende - med Salvestro og Bernardo som rejseførere - tager på en pigrimsfærd til Rom for at redde deres smuldrende kirke. I Rom bliver det umage makkerpar, der minder påfaldende om Asterix og Obelix, uforvarende viklet ind $i$ en historisk intrige, som de ihærdigt men uden at spekulere nærmere over de dybere implikationer - spiller deres rolle i:

Pave Leo X står for at skulle opdele Verden $i$ interessesfærer mellem Portugal og Spanien, og for at opnå Pavens gunst sender de to nationer ekspeditioner afsted for at finde et næsehorn til ham. Paven drømmer nemlig om en storslaet kamp mellem sin kæleelefant Hanno og et næsehorn, der ifølge Plinius' Naturalis historia er elefantens ærkerival. Jagten på det underlige dyr, der ikke har været set i Europa siden Antikken, strækker sig efterfølgende over tre kontinenter og utallige eventyr, inden paven langt om længe får sit ønske opfyldt og overværer den dommedagsagtige kamp mellem elefanten og næsehornet (sidstnævnte er dog udstoppet, hvilket imidlertid ikke påvirker kampens underholdninosværdi).

De to forhutlede hovedpersoner i The Pope's Rhinoceros har det måske endnu sværere end John Lemprière. Først og fremmest har de ikke den belæste Johns intellektuelle kapacitet. Salvestro er ganske vist forholdsvis snarrådig, og kan begå sig i mange sammenhænge, men et medlemsskab i Mensa er alligevel ikke videre sandsynligt. Og hans ven Bernardo, den 7 fod høje kæmpe (og det var mange fod i gamle dage!), er direkte en sinke. Hvor John bekymrede sig om at finde skjulte mønstre, at afdække magtmisbrug og multinationale handelsaftaler, der bekymrer Bernardo sig om at undgå at få klippestykker i hovedet. Og når han ikke tænker pà dét, så traker han på at undgå a blive bidt a f hunde. Salvestro bar pa sin side nok at gore med at pase pa sin simple ven, sant med at huke tibge pa

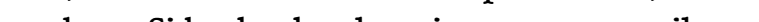
af hjemløshed og flakket omkring på det krigshærgede europæiske kontinent.

Den topografi, Salvestro og Bernardo bevæger sig rundt $i$ og igennem, er endvidere mindst lige så uoverskuelig og truende som i Lemprière's Dictionary. I Rom befinder de to sig $i$ en veritabel urskov af in- 


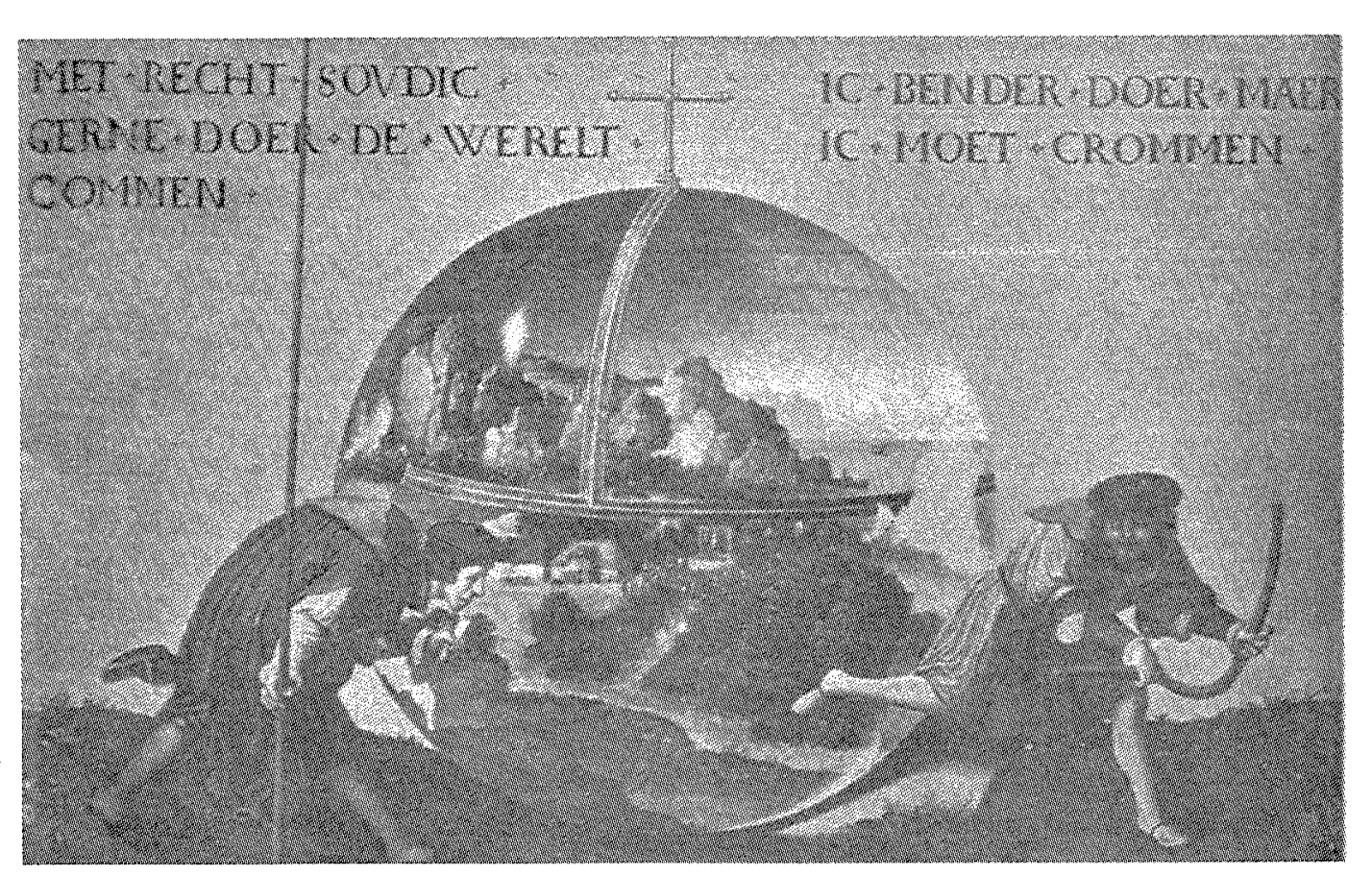

Nederlandsk (effer Jocctrm PatrinR?): Man mä boje sig for at komme gennem verden. (2. halvdel af det ro. arhundrede).

triger omkring pavehoffet, og på deres senere rejse efter næsehornet stifter de bekendtskab med en ægte urskov i centrum af hjertet af det mørke Afrika. Som en hovedregel aner de ikke, hvor de befinder sig, eller hvad der foregår omkring dem. Også læseren bliver sat på en større prøve i The Pope's Rhinoceros. Den tekstlige geografi, sproget, er ofte meget tæt, og man må hvæsse den åndelige machete for at hugge sig vej. Kronologien er desuden endnu mere opbrudt end i debutromanen, og bogen nærmer sig derfor en ren spatial form. Episoder er flettet ind $i$ hinanden, andre foregår parallelt. Flashbacks og flashforwards river teksten $i$ bver sin backs og tash ort det yerligere det yderligere. Roment slutningen på del 3, og leder op til den, sådan at årsag og virkning byttes om $\mathrm{i}$ tekstens brudstykkeagtige rum, der er "brudt op i fragmenter, og selv fragmenterne flossedes og trævledes. " ${ }^{\text {Ir }}$

For at sige noget mere præcist om romanen struktur og om læserens plads i dens topografi, kan man endnu en gang ty til en nærlæsning af nogle af dens mange mise-en-abyme-strukturer. Norfolk e virkelig forfalden til dette tekstgreb, der kan siges at være et topografisk kneb, idet det baserer sig på strukturgenkendelse som enhver anden form for navigation. En mise-en-abyme kan forme sig på mange forskellige måder: Som et skuespil i skuespillet (Hamlet) eller som en beskrivelse af et billede, der rummer elementer af plottet (altertavlen i Rosens navn, guldmønten i Moby-Dick). Norfolks foretrulene er dog uden tvivl landskabsbeskrivelsen, eller alternativt beskrivelsen af bygninger/byer. Beskrivelserne antager en dybere resonans og bliver figurer på teksten selv, samt på lesningens vilkår. På denne made dones der en beroing denne måde dannes der en berøringsflade mellem roller.

Tag for eksempel beskrivelsen af en sildestime i farvandet ud for Usedom. Sildene står i stimer og ser på de fragmenter, som overfladestorme sender ned til dem $\mathrm{i}$ deres mørke dyb. Uforbundne ting synker ned gennem havvandet og fortæller fragmenteret om, hvad der sker på overfladen: „Det er en gåde, eller rettere brikkerne $i$ et puslespil ... Det er mere end mærkværdigt ... det [er] svært at sætte disse ting $\mathrm{i}$ forbindelse [engelsk: relate] med hinanden ... Alene omfanget [engelsk: volume] gør hensigten påtrængende, men hvad kan disse sprællere og synkere mon håbe på at opnå ved så mangfoldigt et offer, så inkonsekvent en overflod? En sådan vedholdenhed sionalerer enorme årsager" (PR, 70-72). (PR, 70-72). Læseren, og Salvestro og Bento, skal som sildene forsøge at for. skabe mening. The Pope's Rhinoceros tilbyder information, men betydningen må vi for en stor dels vedkommende selv tilfoje. Sidepassagens dobbelte bund træder tydeligt frem på engelsk, hvor "relate både kan betyde 'forbinde' og 'fortælle', og hvor "volume“" betyder 'mængde' såvel som 'bogbind'. Beskrivelsen af bogen som et oprort hav har mange ekkoer gennem romanen, hvor Norfolk bl.a. tale om „en ny og flydende topografi“ (PR, 238).

I en anden topografisk mise-en-abyme er Salvestro faret vild i den afrikanske jungle og bevæger sis forvirret rundt i den tætte vegetation:

Men til siden, til siden... Kæmpemæssige sorte stammer hæver sig over de nedre trakkoners sperttede pukler og stotter de $\varnothing$ res hule kupler [...] "Over" er lidt lysere end „under", men begge består de af uhåndgribeligt lov, som om de var hinandens spejlinger, bare billeder, der strakker sig over hele skoven. Der hersker dimensionsforvirring i denne mellemzone (hvad er højde egentlig?), hvor egem, firben, mindre aber os chimpanser klatrer op og ned uden åbenlyst at skelne mellem disse radikalt forskellige manovrer, og så langt fra at levere de manglende koordinater fremturer de hoffardige træer blot deres årtier lange morderiske springen buk. [...] „Op“ og "Ned" er i sig selv i drift og i sitrende bevegelse, de bytter plads og trakker den vertikale akse ud af plan og ind i serpentineslynoninger, skæevvridninger, lemniskare drejninger tineslyngninges, moddrejninger... Her nuter

Det er dér, Salvestro befinder sig, under Nedenunder,

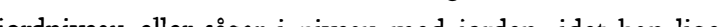
sublet over en af de beswed jorden, idet han lige

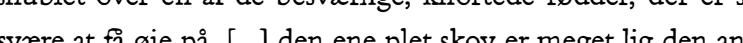

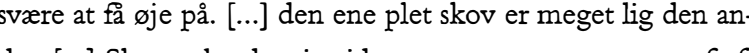
den [...] Skoven breder sig sideværts gennem en proces af e. terligninger og analogier. Papegojeme er dens herolder, og urtidskamæleonen dens konge: Der kommer han, spæettet eller marmoreret alt efter terrenet, idet han lofter et leddelt ben ad gangen og sxtter det ned igen med overdreven varsomhed, som om jorden stadig var blød, som om et enkelt fejltrin ville være nok til, at han sank boblende ned i det mudder, der dækkede alting $i$ tiden, inden Eri hærdede det og forvandlede det til den jord, hvis beskaffenhed afgør alting her og er dets patologi og udvaskede grammatik..

(PR, 618-20)

Selv om citatet er laaangt er det kun et mindre udpluk af en længere passage, der strækker sig over 6 tætskrevne sider $i$ romanen. Men pointen er vist klar. Sproget bliver pludselig tæt og uigennemtrængeligt og gør det vanskeligt at se 'ind' til Salvestro. Prosaen antager en egen monstros materialitet og bliver til en jungle $i$ en beskrivelse af en jungle, der samtidig er en beskrivelse af romanen selv. Ligheden mellem sproget og junglen understreges af ordet 'grammatik', der er usædvanligt i en naturbeskrivelse. Salvestro har bogstaveligt talt næsen i mulden (han er snublet), og det samme har forgæves forsøger at tilkæmpe sig et overblik.

I episoder som den ovenstående sættes der altså I episoder som den ovenstående sættes der altså lighedstegn mellem sproget og det topografiske, således at formen så at sige får sit eget indhold. ${ }^{\mathrm{I}} \mathrm{Et}$ andet og meget kortere eksempel på sidestillingen af sproget med et sted finder vi i titlen på romanens anden del, „Ro-ma“. Titlen angiver et geografisk sted, men lægger samtidig vægt på det fysiske/materielle aspekt ved sproget, gennem brugen af lydskrift.

Hvor Lemprière's Dictionary slutter med et altseende gudeperspektiv, så begynder The Pope's Rhinoceros mere ydmygt: ikke engang med et froperspektiv froer har trods alt en vis vardighed (de han blive til prinser) priner) pheste rebrod dende perspektiv sætter dagsordenen for resten af romanen. Som vi sá, befinder Salvestro sig ikke blot i 'jordniveau', men endog ' $i$ niveau med jorden'. Septimus' svimlende flyveture (og læserens ridt på ryggen af ham) er en saga blot i Norfolks anden roman. Der ér ganske vist også en engel med i The Pope's Rhinoceros: Hun hedder Amalia og er 8 år, 
men selv om hun i sine lege snurrer nok så hurtigt rundt om sig selv, så letter hun ikke. Debutromanens betydningsskabende vertikale perspektiver er nu skåret bort, og tilbage har vi det horisontale plan at bevege os på. Desuden har vi ikke lengere den tryghed, at begivenhederne er fortalt $i$ datidere den terid. Datidsformen Lemprière's Ditionar, og dens apokalyptiske objektivitet ${ }^{13}$ var en naturlig forlængelse af fugleperspektivernes priviligerede klarsyn - den bragte begivenhederne på sikker afstand, og indgav følelsen af overstaet, skrevet historie. The Pope's Rhinoceros er derimod forst og fremmest fortalt $i$ nutid, fra begivenhedernes midte, en simpel men effektiv metode til at suge læseren med ind i romanens univers. En anden strategi, Norfolk benytter for at inkludere læseren, er at starte mange scener uden deiktiske markører overhovedet. Manglen på steds- eller personangivelser $\mathrm{i}$ begyndelsen af en scene har en stærkt deserienterende effelt pa lesene har en starkt desorient ing vis. Situr vis. Siturion helt mørkt rum bevæbnet med blot en lille lommelygte. Man kan ikke med det samme fà et overblik over rummets beskaffenhed, men må langsom stykke et billede sammen ved at lade lysstrålen glide rundt i lokalet.

Som et naturligt resultat af de forskellige desorienterende strategier er to af romanens gennemgàende figurer hjemloshed og tvivl. De to figurer er både betegnende for Salvestro og Bernardo, og for læseren. Salvestro er gennem hele romanen på jagt efter et hjem. Selv på sin fodeø Usedom blev han og moderen betragtet som fremmede, og det eneste 'bjem' han nogensinde har haft var moderens eventigen han nogensinde har haft var moderens eventyrlige fortalliger om den susedoms nordige kyst. Rome by Vis med at Salvestro vender 'hjem' til Vineta, men da hans hjemkomst er ensbetydende med druknedoden, kan bogen vel næppe siges at følge en traditionel hjemme-ud-hjem-struktur. I manglen på faste holdepunkter og centralperspektiver kan læseren også siges at befinde sig $i$ en tilstand af hjemløshe og fundamental tvivl; tvivl om hvad der overhovedet sker, og hvorfor det egentlig sker. Tvivlen går igen på alle romanens niveauer og udstrækker sig endog til at omfatte dens helt centrale symbol: næsehornet. Man må huske på, at næsehornet i r ISIS var et ukendt dyr i Europa, kun kendt gennem forskellige antikke skrifter. For at understrege dette skellige antikke skrifter. For at understrege dette forhold nævner Norfolk kun næsehornet ved den navn én eneste gang, nemlig $i$ romanens titel. Alle romanpersonerne kalder ellers dyret for 'Dyre' (undtagen Bernardo, som har hørt nogen nævne, at bæstet er 'en Enigma' og derfor tror at dét er dyrets navn). I kraft af sin på én gang helt centrale placering og sin ikke-tilstedeværelse bliver Dyret en slags blankt symbol, der minder om Hvalen i Moby-Dick - et symbol der kan rumme så mange forskellige betydninger, at det i sidste ende sprænges og bliver meningsløst. Det udstoppede næsehorn kommer da også til at spændes ud af så mange fortolkninger (og gæret brød), at det til sidst eksploderer i den storslåede kamp med pavens elefant. ${ }^{.4}$

Når man til stadighed belejres af hjemløshed og tvivl, og når man ikke har adgang til opklarende perspektiver fra oven, hvordan kan man så styre uden om heksen i pandekagehuset? Hvordan undgår man at fare vild, og hvorledes skabes der mening i denne roman, der $i$ en af mange mise-en-abymestrukturer beskrives som en tæt mangrovesump $(\mathrm{PR}, 522)$ ? I endnu en topografisk mise-en-abyme, en beskrivelse af Roms uden sammenligning værste pensionat, antydes muligheden af, at det trods alt er muligt at opnå en vis klarhed:

Krystaløjeblikket venter et sted herinde.

Der er gange og korridorer, krumninger, hjørner, pletter og trapper, og disse forhindringer udgor i sig selv en vanskelighed. Men han vil finde klarhed $i$ disse koordinater, i denne forfaldne geografi.

(PR, 409)

Der er altså håb forude og hjælp at hente i romanens „forfaldne geografi“, dens „dimensionsforvirring“ som det hedder $i$ den tidligere citerede junglepassage. Og netop i junglepassagen er der et af romanens sjældne krystaløjeblikke. Der hænger nemlig en plukkemoden frugt, som man måske ikke fik øje på første gang man kæmpede sig gennem den sammenfiltrede sprogvegetation med Salvestro: „den ene plet skov er meget lig den anden [...] Skoven breder sig sideværts gennem en proces af efterligninger og analogier" (PR, 6r9-20). I dette korte cininger og a is tat 'udtrylkes I koncentreret form The Pope Rhinoceros horiso struktureringsprincip. Lige

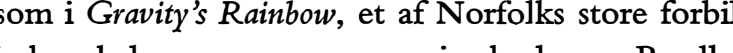
leder, skal romanens mange episoder læses „Paralle not series“" (Gravity's Rainbow, s. I59). I stedet for traditionelle, lineære bevægelsesmønstre bør læseren søge analogier på tværs af romanens forskellige niveauer, optegne ligheder og isomorfier. Gennem sådan et non-lineært fortolkningsmønster vil man opdage, at ,"det ene stykke hav ligner [...] det andet en hel del“ (PR, 439), eller at "den ene plet skov er meget lig den anden..." (PR, 6rg). Aposiopesen det sidste af de to citater virker emfatisk og viser indirekte tilbage til det forste citàt. De to citater taler ike blot om strukturighed men praktiserer det ogsa ved at vare stort set ens. Is Gen prot og ved at vare stot set ens, is Genten af næste den samme szert skaber en fortætning af betydning, en form for redundans, der sikrer at beskeden når frem, hvis blot læseren e lidt opmærksom.

Der er i det hele taget utallige episoder/figurer/ symboler osv., der gentager sig i forskellige variationer i løbet af romanen. Som tidligere nævnt er det monstrøse en gennemgående figur, både på personplanet og på metaplanet. Romanen rummer endvidere to sørejser, der minder påfaldende om hinanden; og så er der byen Vineta, der knækker af øen Usedom $i$ en storm - en struktur der går igen $i$ beskrivelsen af den belejrede by Prato, og i romanens slutning der på sin vis er 'knækket' fra resten handlingen og synker $i$ skjul i havet.

Det er et hårdt arbejde at afdække de mange analogier, men de ér til stede som en stadig understrom. "Støt aflejring, dét er løsenet“ (PR, 74) i fortolkningen af romanen. De mange åbenlyse og mere fordækte gentagelser $i$ bogens rum skaber fortæ ninger af betydning, og betydningen i The Pope Rhinoceros er altså snarere et resultat af ligheder en af forskelle. ${ }^{\text {.7 }} \mathrm{Et}$ af romanens mest gennemgående stiltræk er da også sammensmeltningen, der måske gør det svært at skelne mellem flere individuelle entiteter, men som til gengæld danner koncentrater af betydning. De mange intrigante ambassadører og hofsnoge i Rom er f.eks. svære at holde ude fra hinanden: ,De er kopier af hinanden, ikke til at skelne fra hverandre" ( $P R, 24 \mathrm{r})$, eller andetsteds: Ansig-

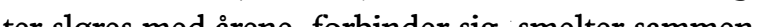

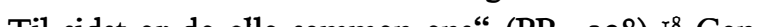
man ilke skelne hofnegent den paven tet gengæld udgør de et præcist portræt af pursen pà dybdepsykologiske personportratter opvejes af $-j a$, resulterer i det sammensatte portræt af en by og en tid. Ved at opfatte The Pope's Rhinoceros som et rum, der skal kortlægges i netværksstrukturer af analogier, eller som en mangrovesump, man kan sejle rundt i i de små skibe, der optræder som en vignet mellem hver episode, kan man opnå en fortolkning som ilke er tilgnelig via traditionelle, plotforbundne lesemåder. På dene mide estates der arter et Dostuleves i Lempires Dicionar. Dete fett tor for læserens egen regning og er en stadigt fortløbende proces, der ikke fastryses af panoptiske perspektiver: "Disse muligheder blandede sig og kolliderede, og deres forskellige aktører smeltede sammen inden for dem" (PR, 52I).

De åbne strukturer, som postuleres i Lemprière's Dictionary, kan altsà realiseres i The Pope's Rhinoceros, og som sådan kan Norfolks første roman siges at udgøre en glimrende kompagnon til læsningen af hans anden. Beskrivelsen af Kejser Josefs sædspor rammer f.eks. lige i øjet hvad angår The Pope's Rhinoceros, der jo netop er en ræake kaotiske vektorer, som indimellem modes $i$ konvergenspunkter $i$ romanens mulighedffl I Norfolks seneste roman in ikke er nogen alvidende engel til at udpege dem. Løfterne fra Lemprière's Dictionary indfries i The Pope's Rhinoceros, hvor læseren fâr lov til at have sine helt egne våde drømme...

Det æstetiske skift mellem de to romaner har også vidtrækkende etiske konsekvenser. Hvor laseren (og John Lemprière) i debutromanen ender med at 
indtage rollen som 'udvalgt' - en moralsk betænkelig position - forbliver han 'forbigàet' i efterfølgeren. Guderollen er simpelt hen ikke en mulighed i den anden romans horisontale rum, hvor læseren og hovedpersonerne forenes $\mathrm{i}$ jordhøjde, med næsen helt nede i mulden. Vi kan ikke bare lane os tilbage og se 'ned' på begive hederne, men ma selv eget tidligere roman:

Gør dig derfor ulejlighed i denne sag [...] vi vil ikke tjene din dovenskab, hvor intet andet end din egen opmerksomhed er fornøden, thi du tager i høj grad fejl, hvis du tròr, at vi, da begyndte på dette store vark, havde til hensigt ikke at give din klogt noget at bestulle, eller at du uden stundom at praktisere dette talent vil vere i stand til at rejse gennem vore sider med nogen glede eller fordel for dig selv.

(Tom Jones, XI, 9 )

Norfolk slipper læseren løs $\mathrm{i}$ tekstens topografi, men vi kan godt opgive enhver tanke om at kontrollere vi kan godt opgive enhver tanke on at kontrollere den ganke sinpelt for komplets og uove den ganske simpet for kompleks og uoverskuelig ligesom r500-tallets for en stor del ukortlagte verden var uoverskuelig for datidens opdagelsesrejsende, og ligesom vore dages informationssamfun er alt for komplekst til at man kan gøre sig håb om at danne et overblik.

The Pope's Rhinoceros knytter på forbilledlig vis det æstetiske/strukturelle sammen med det etiske og det alment menneskelige. På sin vis er det naturligt, at Norfolks første roman skulle benytte sig af panoptiske perspektiver - den foregår midt i Oplysningstiden, få år efter brødrene Montgolfiers første ballonfart i 1783 - men den ender altso med at indtage den kontolpositon, den tidligere har bitiser. den kon or Kaos og or Din boldes def tide, o Lemprienes Dithonas indiver felelsen af shrevet $\mathrm{H}$ storie. The Pope's Rhinoceros formar i langt højere grad at integrere kaos og orden ved at give læsere mere eller mindre frie tøjler i sin horisontale topografi; ved i lynsnare glimt at lade ham øjne „et mønster i et sammensurium af former" (PR, 398), de imidlertid opløses igen sá snart han vender rygge tii. Romanens vellykkede projekt er at skildre Hi- storien som levet snarere end skrevet, at forankre den 1 det menneskelige og afspejle vores daglige kamp for at danne en lille gnist af mening $i$ en uoverskuelig verden. I en anden monstrøs roman, Manden uden egenskaber, lader Robert Musil sin hovedperson Ulrich reflektere over forholdet mellem levet og shevet Historie: Vor historie ser mellem er usikke og sammenfiltret $u d$ når man betragter den på nær hold, men når alt kommer til alt, går der alligevel sælsomt nok en vej hen over den, nemlig den 'Historiens Vej', om hvilken ingen véd, hvorfra den kommer." "Ig I Lemprière's Dictionary viser Norfolk os i sidste ende en sikker vej gennem sumpen. I The Pope's Rhinoceros har vi ingen hjelper, intet kort. V må selv - som Salvestro og Bernardo da de flygter fra rædslerne i Prato - finde „den enlige sti, de eneste sikre passage, den usynlige, snoede linie, som lå skjult under mosens overflade“" $(\mathrm{PR}, 375)$. Ellers.

Note

I. Los Angeles i Steve Ericksons romaner, mosen i Graham Swifts Waterlands og London i Martin Amis' Londo Fields er alle eksempler på steder, der snarere er aktorer end blot baggrund for romanpersonernes gøren og laden 2. I et brev til forfatteren, I6. oktober 1998 .

3. Og den engelske udgave er endnu storre end den danpa hver sin side of Atlanten. I den aret forskellige udgaver nesten en femtedel af den engelske udgave udgave var med diverse uheldige folger. Af uforklarlige årsager valgte de danske forlæggere at oversætte den amerikanske udgave. Jeg har $i$ artiklen fortolket den engelske udgave. Hvor det er muligt, har jeg citeret fra Thomas Harders ovrigt glimrende oversettelse (Lemprières ordbog, Kbh., 1993), resten er mine egne oversættelser. Sidehenvisning eme vil dog fortsat være til den komplette, engelske u gave, og vil optrode parentetisk i telsten, saledes: (ID,

4. Tristero er navnet på den hemmelige postorganisation, der opererer $\mathrm{i}$ kulisserne af Pynchons The Crying of Lot 49 . O'Tristero, en ,ubestemmelig fyr “, der klart viser hen ti den hemmelighedsfulde Pynchon, optreder på side 200or i Lemprière's Dictionary, hvor han presenterer sig som Johns rival, for derefter at forsvinde for resten af romanen. version. Man kan kun hảbe, at Munksgaard/Rosinante ger sig sammen og udgiver en oversæettelse af den engelske version, en director's cut.
6. Det ofte misbrugte begreb 'fraktaler' betegner netop en struktur der går igen på flere forskellige niveauer, ell med ægte kaosteoretisk terminologi: „Selv-lighed er symmetri twærs over skalaer. Den indebærer gentagelse, monster inden i of (228). 8. Vineeta er navnet på Norfolks hustru, mens Vineta er en faktisk sunken by (eller $i$ hvert fald en faktisk legende om en sunken by).

9. Bemærk at romanen endnu en gang foregår umiddelbart for en historisk omvæltming.

ro. Denne gang spiller en alpe-citarist Hendrix' Purple Haze ved pavehoffet i isı6. Så er anakronismen vist så fed utilsigtet.

Ir. The Pope's Rhinoceros, s. 407. Jeg citerer også her fra
Thomas Harders overssttelse (Pavens nasehorn, I996), men vil fortsat henvise til den engelsk udgave. Fremover vil sidehenvisningerne optrede parentetisk teksten, således: (PR, oo)

I2. Et tidligere eksempel på denne strategi finder vi i Nabokovs Pale Fire, hvor Charles Kinbote - efter at have skildret afstanden mellem to huse $i$ en lang passage - siger: „Det er sandsynligvis forste gang, at afstandens slov grafisk ide far verbalt ud st ilistisk efekt, og at en topograls ire, Everyman's Library 92, m.o.). Hos Norfolk er teknikken dog både hyppigere og mere gennemfort.

13. Udtrykket er Michel Foucaults og betegner en kunstigt indtaget synsvinkel hinsides begivenhederne; en synswinkel der fungerer som en kompleksitetsreduktion os muliggør en falsk objektivitet. Se essayet "Nietzsche, Genealogy, History

14. I kraft af sin storrelse bliver næsehornet også et billede pà romanen selv, eller vice versa. Adjektivet 'monstros' af nesehornet men ossa $i$ forbindelse med personer som Bernardo, og den flommefede Fiametta. Og endelig er den bog, hvis cover omslutter disse monstrositeter, og selv monstros i den 3 pund tunge hardcover-udgave. Is. Dette er især tydeligt på engelsk, hvor de to sætninger hedder: "one patch of ocean is much like another" o "one patch of forest is much like another", altså kun ét ord forskel. Hvis Thomas Harders gode oversettelse af roma6. Jeg anvender her ordet 'redundans' i dets positive, 16.Jeg anvender her ordet 'redundans' $i$ dets positive, intur, der sørger for at informationen når intakt fra afsender til modtager, uden at forvrænges af støj.

7. Jvnf. Katherine Hayles' diskussion af Gravity's Rainbow i The Cosmic Web.
I8. Andre eksempler på sammensmeltrninger kan findes på bla. siderne 76, I68, I8I, 20I, 238, 386 (og det er kun et sparsomt udvalg)

I9. Fra kapitlet "Sligt sker, eller hvorfor opfinder man kke Historie?", i Manden uden egenskaber, bind 2, s. 65

Litteratur

Bellante, John \& Carl: „Lawrence Norfolk, Nouveau Navigator of Antiquity" (interview med Lawrence Norfolk); The Bloomsbury Review, March/April I993; pp. I4-I6
Elias, Amy J.: The Postmodern Turn on (:) the Enlightenment"; Contemporary Literature 37, \#4 (I996); pp. 533Ferguson, Niall (ed.): Virtual History - Alternatives and Counterfactuals; Papermac, London; I 998

Fielding, Henry: Tom Jones; Everyman's Library, New York; 1991 (1749)

Foucault, Michel: „Nietzsche, Genealogy, History“; pp.
I39-64 in Language, Counter-memory Practice. Basil Black139-64 in Language, Counter-memory, Practice; Basil Black-
well, Oxford; 1977 (Oversat af Donald F Bouchard) -. Discipline and Punish; Penguin, London; rggr (Oversat af Alan Sheridan)

Gleick, James: Chaos - Making a New Science; Abacus, London; 1993 (1987)

Ples, Katherine: The Cosmic Web - Scientific Field Models \& Literary Strategies in the 20th Century; Cornell University Hutcheon, Linda: $A$ P

Hoscheon, Linda: $A$ Poetics of Postmodernism; Routledge, London; 1996 (1988)

Pric: „Postmodernism, or, the Cultural Logic Kjerstad, Jan: „Menneskets felt“; Kritik \# IIr, 1994; pp.

McHale, Brian: Constructing Postmodernism; Routledge, London; 1992

Lemprière's Dictionary; Minerva, London; 1996 (I99I)

-. The Pope's Rhinoceros; Minerva, London; 1997 (1996) med Lawrence Norfolk); Griflen, dec. 1993; p. I7 Poole, Steven: „The Horn of Plenty“ (interview med Lawrence Norfolk); The Guardian, April 26, 1996; suppt. p. I7
Pynch Pynchon, Thomas: Gravity's Rainbow; Viking, New York; I973 hite, Hayden: The Content of the Form: Narrative Discourse and Historical Representation:
sity Press, Baltimore; 1990 ( 1987$)$ 